\title{
MAXIMIZING SUGAR BEET YIELD, QUALITY AND WATER USE EFFICIENCY USING SOME AGRICULTURAL PRACTICES UNDER NORTH SINAI CONDITIONS
}

(Received:16.11.2008)

\author{
By \\ E. I. El-Sarag

\begin{abstract}
Department of Plant Production, Faculty of Environmental Agricultural Sciences, El-Arish,
\end{abstract} \\ Suez Canal University, Egypt.
}

\begin{abstract}
Two field experiments in two successive seasons of 2006/2007 and 2007/2008 were conducted in the Experimental Farm of Environmental Agricultural Sciences Faculty, El-Arish, Suez Canal University, North Sinai Governorate. This study focuses on the effect of three irrigation intervals (every 5, 8 and 11 days), three plant densities (20,28 and 46 thousand plants fed ${ }^{-1}$, which resulted from three hill spacings namely 35,25 and $20 \mathrm{~cm}$, respectively) and four nitrogen fertilizer rates (60, 80,100 and $120 \mathrm{~kg} \mathrm{~N} \mathrm{fed}^{-1}$ ) on growth, yield, juice quality and water relationships of multigerm sugar beet cultivar Farida. Soil texture was sandy clay with $\mathrm{pH}$ 7.44. Drip irrigation system with an average of $4100 \mathrm{ppm}$ water salinity was used. The experimental unit area was $18 \mathrm{~m}^{2}$ (6 rows; $60 \mathrm{~cm}$ width $\mathrm{x} 5$ $\mathrm{m}$ length) and the sowing dates were $20^{\text {th }} \& 25^{\text {th }}$ Oct. in the two respective seasons. Results showed that increasing irrigation intervals from 5 to 11 days sharply reduced top fresh weight and consumptive use, while, irrigation every 8 days was superior in root and sugar yields as well as water use efficiency (wu) in both seasons. However, 11- day treatment gave the highest sucrose percentage in both seasons and maximum purity percentage in the first season only. There were insignificant effects of plant

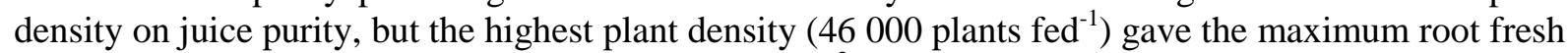
weight and sugar yield as well as WUE ( $\mathrm{kg}$ sugar $\mathrm{m}^{-3}$ water) as compared with the lowest densities. Increasing nitrogen fertilizer rates from 60 up to $120 \mathrm{~kg} \mathrm{~N}^{-1}$ substantialy improved most of the studied growth criteria and root yield as well as WUE. Meanwhile, adding $100 \mathrm{~kg} \mathrm{~N} \mathrm{fed}^{-1}$ gave the optimum sugar yield and CU. The highest sucrose and purity percentage were gained with the lowest nitrogen fertilizer rate $\left(60 \mathrm{~kg} \mathrm{~N}\right.$ fed $\left.^{-1}\right)$.

Irrigating sugar beet every 8 days with plant density of 46,000 plant/ fed and applying nitrogen fertilizer at the rate of $100 \mathrm{~kg} \mathrm{~N}$ fed $^{-1}$ could be recommended for maximum root and sugar yields as well as the most effective use of irrigation water under newly reclaimed soils of North Sinai Governorate.
\end{abstract}

Key words: consumptive use $(C U)$ and juice quality, growth criteria, irrigation intervals, nitrogen fertilizer rates, plant density, root and sugar yields,Sugar beet, water use efficiency (WUE).

\section{INTRODUCTION}

Sugar beet has got importance as a source for sugar production in Egypt. It has been introduced to minimize the gap between sugar production and its consumption. Suagr beet is a vital crop as a source of high energy and as an important source of feed for livstock. It is a winter crop tolerates poor and saline soil. Therefore, it could be economically grown in the newly reclaimed areas with sandy soils as in North Sinai region and enhances soil conditions for the benefit of the following crops. So, reclaiming poor and saline sandy soil and producing sugar out of it, is considered a target for minimizing the shortage of sugar production. Under newly reclaimed sandy soil conditions, improvement of sugar beet production can be achieved through standardization of irrigation interval, plant density and nitrogen fertilizer rate.

Sugar beet could be efficiently grown under a wide range of irrigation levels, where it is readily adapted to limited irrigation because plants utilize deep stored soil water and recover quickly following water stress (Winter, 1980). 
Dunham (1993) showed that sugar beet is adversely affected by waterlogging. Meanwhile, he concluded that there are two reasons for the slowing of leaves enlargement and the storage process in roots as stress develop : lower turgor potential resulting in slower cell expansion and smaller stomatal conductance resulting in less carbon dioxide uptake for dry matter production. Increasing soil moisture depletion from 40 to 80 $\%$ decreased sharply root yield from 32.16 to 16.81 ton $\mathrm{fed}^{-1}$ and root weight from 804 to 453 $\mathrm{g} /$ plant (Sorour, 1995). The maximum values of water use efficiency either as root or sugar per $\mathrm{m}^{3}$ water were recorded when sugar beet plants were irrigated when soil moisture reached $60 \%$ (Besheit et al.,1996) and $65 \%$ field capacity (Mohamed et al., 2000). , Khater (1999) stated that sucrose percentage of sugar beet roots increased with increasing irrigation intervals. On the other hand, irrigation intervals had no significant effect on sucrose percentage (Azzazy, 1998). Also, Shams EL- Din (2000) indicated that soil moisture depth of $30 \mathrm{~cm}$ produced the highest sugar beet yield, meanwhile, sucrose percentage and sugar yield was not siginficantly affected by different levels of water applied. Otherwise, Fabeiro et al. (2003) reported that maximum water use efficiency $(170.55 \mathrm{~kg}$ $\mathrm{root} / \mathrm{ha} / \mathrm{mm}$ ) was gained from the lowest volume of received water $\left(6500 \mathrm{~m}^{3} / \mathrm{ha}\right)$. However, ELMaghraby et al. (2008) recorded that irrigation every 4 weeks gave the highest root and sugar yields as well as juice purity percentage when compraed with irrigation every 6 and/or 8 weeks. They added that significant increases were found in total soluble solids and sucrose percentages by increasing irrigation intervals up to 6 weeks. Thus, improvement of sugar beet production and quality can be achieved through optimizing irrigation intervals.

Since light interception by the crop canopy is an important factor for photosynthesis, the plant density in the field plays a determinate role in dry matter production, thus affecting crop yield. In this concern, increasing hill spacings from 15 to 20 or $25 \mathrm{~cm}$ increased significantly roots, tops and sugar yields (ton/fed) but no significant effect was found on sucrose and purity percentages (Yousif, 2001 and EL-sayed, 2006). On the other hand, Taleghani et al. (2004) in Iran, indicated that the highest sugar yield (8.17 ton/ha) and lowest water consumption $\left(12000 \mathrm{~m}^{3} / \mathrm{ha}\right)$ were obtained with row spacing of $50 \times 40 \mathrm{~cm}$ as compared with $60 \times 40 \mathrm{~cm}$ treatment under surface irrigation system.
However, under Alexandria conditions, the lowest plant density $(20,000$ plants/fed $)$ produced the highest root yield per feddan, total soluble solids percentage and the lowest sugar yield as compared with the highest plant density (46,000 plants/fed) (EL-Maghraby et al., 2008). They added that no significant effect of plant densities on sucrose and purity percentages. Therefore, planting sugar beet on suitable plant density according to environmental conditions of the region is helpful in maximizing sugar beet yield and quality.

Fertilization is among the vital factors affecting growth, yield and quality of sugar beet especially nitrogen. Over the past 20 years, progress was made towards optimizing the use of nitrogen through better understanding of crop requirement under varying conditoins of soil and climate. This is because of nitrogen pronounced effect on growth and physiological processes of sugar beet. Also, nitrogen is referred as a balance wheel of sugar beet nutrition due to the fact that the efficiency of other nutrients is based on it. As the newly reclaimed sandy soils are poor and suffered from low content of nitrogen, therfore, yields were drastically reduced. In this respect, increasing nitrogen rates from 90 to $120 \mathrm{~kg}$ $\mathrm{n} /$ fed. improved root and top weight per plant as well as root and sugar yields (EL-Kassed et al., 1993; EL-Maghraby et al.,1998; Basha, 1999; Ouda et al., 1999; and EL-Shafai, 2000). Also, nitrogen improves accumulating and translocating dry matter from tops to roots, so, determining water use efficiency (WUE) will reflect the optimum benefit of every meter of water and scarce water especially in new reclaimed soils. In this concern, Koszanski and Roy (1995) in Poland, found that increasing nitrogen rate from 0 to $180 \mathrm{~kg} \mathrm{~N}$ fed $^{-1}$ increased WUE. However, EL-Zayat (2000) reported that WUE increased from 11.81 to $12.83 \mathrm{~kg}$ root $/ \mathrm{m}^{3}$ when nitrogen rate increased from 70 to $90 \mathrm{~kg} \mathrm{~N} \mathrm{fed}^{-1}$. Also, the highest values of yield components, root and sugar yields were obtained with increasing nitrogen rates up to $100 \mathrm{~kg}$ N/fed. (Ibrahim et al.,2005); $125 \mathrm{~kg} \mathrm{~N} /$ fed. (EL-Geddawy et al., 2006); $120 \mathrm{~kg} \mathrm{~N} / \mathrm{fed}$. (EL-Geddawy et al., 2008) and $150 \mathrm{~kg} \mathrm{~N} / \mathrm{fed}$. (Seadh, 2008).

Therefore, this study was undertaken to find out the optimal irrigation interval with suitable plant density and nitrogen fertilizer rate to achieve the best productivity and quality of sugar beet under sandy soil conditions of the 
newly reclaimed area in North Sinai Governorate.

\section{MATERIALS AND METHODS}

Two field experiments were carried out at the Experimental Farm of Faculty of Environmental Agricultural Sciences, El-Arish, Suez Canal University, North Sinai Governorate in the two successive growing winter seasons of $2006 / 2008$ in order to study the effect of three irrigation intervals (every 5, 8 and 11 days), three planting densities $(20,28$, and 46 thousand plants $\mathrm{fed}^{-1}$, which resulted from three hill spacings namely 35,25 and $15 \mathrm{~cm}$, respectively) and four nitrogen fertilizer rates $(60,80,100$ and $120 \mathrm{~kg} \mathrm{~N} \mathrm{fed}^{-1}$ ) on growth, yield and quality of multigerm sugar beet cultivar Farida. Sowing took place on the $20^{\text {th }}$ and $25^{\text {th }}$ of October in the two respective seasons. Drip irrigation system was used with water salinity ranged between 3500 and $4600 \mathrm{ppm}$. Irrigation was carried out every two days through the first month then the three studied intervals for 2 hours/irrigation were applied till 15 days before harvest. The mechanical and chemical analysis of the soil at the experimental site is presented in Table 1.

Each experiment included 36 treatments distributed in a split-split plot design with four replications. Irrigation intervals occupied the main plots, while, the sub plots were assigned randomly for three plant densities and the nitrogen fertilzer rates were arranged in the subsub plots. The experimental unit area was $18 \mathrm{~m}^{2}$ (6 rows with $60 \mathrm{~cm}$ width and $5 \mathrm{~m}$ length). The outer two rows were considered as band. The central rows were kept to determine growth, yield and quality. The expermintal field was prepared through ploughing and calcium super phosphate $\left(15.5 \% \mathrm{P}_{2} \mathrm{O}_{5}\right)$ was applied at the rate of $100 \mathrm{~kg} \mathrm{fed}^{-1}$. Potassium sulphate $\left(48 \% \mathrm{~K}_{2} \mathrm{O}\right)$ was added at the rate of $50 \mathrm{~kg} \mathrm{fed}^{-1}$ after thining. Nitrogen fertilizer rates were applied in the form of ammonium nitrate $(33.5 \% \mathrm{~N})$ at the fourth studied rates by side dressing in two equal doses the $1^{\text {st }}$ dose after thinning and the $2^{\text {nd }}$ one 20 days later. Plants were thinned at the age of 35 days from planting to obtain one plant/hill. Plants were kept free from weeds, which were manually controlled by hand hoeing three times. The commen agricultural practices for growing sugar beet were followed according to the recommendations of Ministry of Agriculture and Land Reclamation, Egypt.

\subsection{Data collected :}

At harvest, i.e., 200 days from planting ten guarded plants were chosen randomly from the inner rows of each sub-sub plot to determine the following characters:

\subsubsection{Yield attributes}

2.1.1.1. Top fresh weight ( $\mathrm{kg} / \mathrm{plant})$

2.1.1.2. Root fresh weight ( $\mathrm{kg} / \mathrm{plant})$

2.1.2. Juice quality:

2.1.2.1. Total soluble solides (TSS \%) of fresh roots was determined by using hand refractometer.

2.1.2.2. Sucrose percentage was determined by using Sacharometer according to the method described by Carruthers and Oldfield (1960).

2.1.2.3. Juice purity percentage was determined as by multiplying sucrose percentage $\mathrm{x} 100$ then divided on TSS percentage

\subsubsection{Root and sugar yields}

2.1.3.1.Root yield $\left(\right.$ ton $\mathrm{fed}^{-1}$ ): yield as kg per plot was determined and then converted to ton per feddan

2.1.3.2. Sugar yield (ton $\mathrm{fed}^{-1}$ ) : root yield (ton/fed) was multiplying by sucrose percentage to determined sugar yield (ton/fed).

\subsubsection{Crop-water relationship}

2.1.4.1. Soil samples were taken immediately before irrigation and 24 hours later and oven dried at $105^{\circ} \mathrm{C}$ to calculate water consumptive use (WCU) of sugar beet as mm depth according to the following equation of Israelsen and Hansen (1962) :

$\mathrm{CU}=[(\mathrm{Q} 2-\mathrm{Q} 1) / 100] \times \mathrm{D} \times \mathrm{Db}$

Where:

$\mathrm{CU}=$ water consumptive use in $\mathrm{mm}$

$\mathrm{Q} 2$ = Soil moisture percent after irrigation by weight.

Q1 = Soil moisture percent before irrigation by weight.

$\mathrm{D}=$ Root depth in $\mathrm{mm}$

$\mathrm{Db}=$ Bulk density in $\mathrm{g} / \mathrm{cm}^{3}$

Water consumptive use (CU) of sugar beet as $\mathrm{m}^{3}$ fed $^{-1}$ was calculated as follows :

$\mathrm{CU}\left(\mathrm{m}^{3} \mathrm{fed}^{-1}\right)=\mathrm{CU}(\mathrm{mm}) \times 4.2$

2.1.4.2. Water use efficiency (WUE) was calculated as $\mathrm{kg}$ roots or sugar per $\mathrm{m}^{3}$ of water consumed according to Vites (1965).

\subsection{Statistical analysis:}

Data collected were subjected to the proper statistical analysis of variance of split-split plot design according to the procedures outlined by Snedecor and Cochran (1990). The mean values 
Table (1): Mechanical and chemical analyese of the soil for the experimental site

\begin{tabular}{|c|c|c|c|c|c|c|c|}
\hline \multirow{2}{*}{\multicolumn{2}{|c|}{$\begin{array}{l}\text { Mechanical } \\
\text { analysis }(\%)\end{array}$}} & \multicolumn{6}{|c|}{ Chemical analysis $\left(\mathrm{mg} \mathrm{L}^{-1}\right)(1: 5)$} \\
\hline & & \multicolumn{2}{|c|}{ Parameters } & \multicolumn{2}{|c|}{$\begin{array}{l}\text { Soluble } \\
\text { Cations }\end{array}$} & \multicolumn{2}{|c|}{ Soluble Anions } \\
\hline Sand $(\%)$ & 73 & Organic matter $(\%)$ & 0.62 & $\mathrm{Ca}^{++}$ & 5.3 & $\mathrm{H} \mathrm{CO}^{-1}$ & 6.2 \\
\hline Silt $(\%)$ & 21 & $\mathrm{Ca} \mathrm{CO} 3(\%)$ & 6.11 & $\mathrm{Mg}^{++}$ & 3.2 & $\mathrm{CL}^{-}$ & 15.11 \\
\hline Clay $(\%)$ & 6 & $\mathrm{pH}(1: 2: 5)$ & 7.32 & $\mathrm{~K}^{+}$ & 0.21 & & \\
\hline Texture & $\begin{array}{l}\text { Sandy } \\
\text { loam }\end{array}$ & $\mathrm{EC}$ (m mhos/cm 1:5) & 6.56 & $\mathrm{Na}^{+}$ & 14.8 & $\mathrm{SO}^{-}$ & 1.84 \\
\hline
\end{tabular}

Table (2): Some yield attributes of sugar beet as affected by irrigation intervals in 2006/2007 and 2007/2008 seasons

\begin{tabular}{c|ccc|c}
\hline \hline $\begin{array}{c}\text { Irrigation } \\
\text { intervals } \\
\text { (day) }\end{array}$ & \multicolumn{2}{|c|}{$\begin{array}{c}\text { Top fresh weight } \\
\text { (kg/plant) }\end{array}$} & \multicolumn{2}{c}{$\begin{array}{r}\text { Root fresh weight } \\
\text { (kg/plant) }\end{array}$} \\
\hline Season & $2006 / 2007$ & $2007 / 2008$ & $2006 / 2007$ & $2007 / 2008$ \\
\hline 5 & $0.633 \mathrm{a}$ & $1.064 \mathrm{a}$ & $0.920 \mathrm{~b}$ & $1.212 \mathrm{~b}$ \\
8 & $0.592 \mathrm{~b}$ & $0.863 \mathrm{bc}$ & $1.211 \mathrm{a}$ & $1.406 \mathrm{a}$ \\
11 & $0.515 \mathrm{c}$ & $0.707 \mathrm{c}$ & $0.823 \mathrm{c}$ & $1.033 \mathrm{c}$ \\
F-test & $* *$ & $*$ & $* *$ & $* *$ \\
\hline \hline
\end{tabular}

$*, * *$ and $\mathrm{ns}=$ significant at $\mathrm{P}<0.05,0.01$ levels and not significant, respectively. Means with the same letters are not significantly different at $5 \%$ level.

Table (3): Some yield attributes of sugar beet as affected by plant densities in 2006/2007 and 2007/2008 seasons

\begin{tabular}{|c|c|c|c|c|}
\hline $\begin{array}{l}\text { Plant densities } \\
\left(1000 \text { plantsfed }^{-1}\right)\end{array}$ & \multicolumn{2}{|c|}{$\begin{array}{c}\text { Top fresh weight } \\
(\mathrm{kg} / \text { plant })\end{array}$} & \multicolumn{2}{|c|}{$\begin{array}{c}\text { Root fresh weight } \\
\text { (kg/plant) }\end{array}$} \\
\hline season & $2006 / 2007$ & $2007 / 2008$ & $2006 / 2007$ & $2007 / 2008$ \\
\hline 46 & $0.513 \mathrm{c}$ & $0.510 \mathrm{c}$ & $0.885 \mathrm{~b}$ & $0.886 \mathrm{~b}$ \\
\hline 28 & $0.586 \mathrm{~b}$ & $0.570 \mathrm{~b}$ & $1.225 \mathrm{a}$ & $1.461 \mathrm{a}$ \\
\hline 20 & $0.642 \mathrm{a}$ & $0.662 \mathrm{a}$ & $0.833 \mathrm{c}$ & $0.813 c$ \\
\hline F-test & $* *$ & $* *$ & $* *$ & $* *$ \\
\hline
\end{tabular}

$*, * *$ and $\mathrm{ns}=$ significant at $\mathrm{P}<0.05,0.01$ levels and not significant, respectively. Means with the same letters are not significantly different at $5 \%$ level.

Table (4): Some yield attributes of sugar beet as affected by Nitrogen fertilizer rates in 2006/2007 and 2007/2008 seasons

\begin{tabular}{c|cc|cc}
\hline \hline $\begin{array}{c}\text { N-fertililizer } \\
\text { rates }\left(\mathrm{kgN} \mathrm{fed}^{-1}\right)\end{array}$ & \multicolumn{2}{|c|}{$\begin{array}{c}\text { Top fresh weight } \\
(\mathrm{kg} / \text { plant })\end{array}$} & \multicolumn{2}{c}{$\begin{array}{c}\text { Root fresh weight } \\
(\mathrm{kg} / \mathrm{plant})\end{array}$} \\
\hline Season & $2006 / 2007$ & $2007 / 2008$ & $2006 / 2007$ & $2007 / 2008$ \\
\hline 60 & $0.301 \mathrm{~d}$ & $0.286 \mathrm{~d}$ & $0.772 \mathrm{~d}$ & $0.752 \mathrm{~d}$ \\
80 & $0.345 \mathrm{c}$ & $0.341 \mathrm{c}$ & $0.789 \mathrm{c}$ & $0.770 \mathrm{c}$ \\
100 & $0.432 \mathrm{~b}$ & $0.435 \mathrm{~b}$ & $0.832 \mathrm{~b}$ & $0.855 \mathrm{~b}$ \\
120 & $0.552 \mathrm{a}$ & $0.583 \mathrm{a}$ & $0.853 \mathrm{a}$ & $0.869 \mathrm{a}$ \\
F-test & $* *$ & $* *$ & $* *$ & $* *$ \\
\hline \hline
\end{tabular}

$*, * *$ and $\mathrm{ns}=$ significant at $\mathrm{P}<0.05,0.01$ levels and not significant, respectively. Means with the same letters are not significantly different at $5 \%$ level. 
were compared using Duncan's multiple range test according to Duncan (1990). All statistical analysis were performed by using analysis of variance techneque of (MSTAT) Computer software package.

\section{RESULTS AND DISCUSSION \\ 3.1. Yield attributes: \\ 3.1.1. Effect of irrigation intervals:}

Response of sugar beet yield attributes to different irrigation intervals is shown in Table 2. Remarkable reduction was obtained in top fresh weight per plant in both seasons in response to increasing irrigation intervals. These increases amounted to 6.93 and $22.91 \%$ in 2006/2007 season for 5-day treatment as compared with 8 and 11-day was, respectively. Similar trend was observed in the 2007/2008 season, where, the highest top fresh weight $(1.064 \mathrm{~kg} / \mathrm{plant})$ was optained when plants irrigated every 5 days. The superiority of root fresh weights (1.211 and $1.406 \mathrm{~kg} / \mathrm{plant}$ ) were achieved with 8- days interval in the $1^{s t}$ and $2^{\text {nd }}$ seasons, respectively. The increase in root elongation may be attributed to the increase of abscisic acid concentration in root which clearly promotes elongation under drought conditions and is reflected on dry matter accumulation. Similar results were obtained by Sorour, (1995); Besheit et al. (1996); Mohamed et al. (2000) and El-Maghraby, et al. (2008).

\subsubsection{Effect of plant densities:}

Data illustrated in Table 3 reveal that there was highly significant effect of plant densities on top and root fresh weights per plant in both seasons. The lowest plant density $(20,000$ plants $\mathrm{fed}^{-1}$ ) resulted in the heaviest top fresh weight (0.642 and $0.662 \mathrm{~kg} /$ plant) in 2006/2007 and 2007/2008 seasons, respectively. However, moderate plant density $(28,000$ plants/fed) gave the maximum root fresh weight (1.225 and 1.461 $\left.\mathrm{kg} \mathrm{plant}^{-1}\right)$ in the two respective seasons. These results may refer to the low competition between the plants for light and nutrients under low plant densities. Similar trend was found by Yousif (2001) and Taleghani et al. (2004).

\subsubsection{Effect of nitrogen fertilizer rates:}

Results in Table 4 show a highly significant effect of nitrogen fertilizer rates on yield attributes in both seasons. Increasing nitrogen rates from 60 to $120 \mathrm{~kg} \mathrm{~N}^{-1} \mathrm{~d}^{-1}$ increased top fresh weight by $83.3 \%$ in the first season and was duplicated in the second season. The same trend was found for root fresh weight, where, it increased from 0.772 and $0.752 \mathrm{~kg} / \mathrm{plant}$ up to 0.853 and $0.869 \mathrm{~kg} /$ plant in the two respective seasons. The differences between 100 and 120 $\mathrm{kg} \mathrm{N}$ fed $^{-1}$ on top and root fresh weight were not significant. This means that the response of sugar beet to the highest nitrogen rates $(120 \mathrm{~kg}$ $\mathrm{N} \mathrm{fed}{ }^{-1}$ ) is not economic. These results may refer to the role of nitrogen in encouraging plant uptake of the other elements and activate accumulation of carbohydrates, which are translated from leaves to developing roots, which in turn enhanced root length, diameter as well as root fresh weight per individual plant. Similar results are in coincidence with those stated by Ibrahim et al. (2005) and EL-Geddawy et al. (2008).

\subsection{Juice quality}

Data of juice parameters, which reflected its quality, namely Total Soluble Solids (TSS), Sucrose and purity percentages are presented in Table (5) in response to irrigation intervals, plant densities, nitrogen fertilizer rates.

\subsubsection{Effect of irrigation intervals}

There were significant effects of irrigation intervals on juice quality parameters in both seasons except total soluble solids (TSS) in the $1^{\text {st }}$ season and purity percentage in the second season (Table 5). Irrigation intervals affected significantly at $5 \%$ the level on TSS, where, increasing irrigation intervals from 5 to 11 days increased TSS from 18.82 to 21.33 in the $2^{\text {nd }}$ season. Sucrose percentage appreciably increased corresponding to the reduction in soil moisture level. Where, the highest sucrose percentages (16.28 and $15.33 \%)$ were obtained when sugar beet plants were irrigated every 11 days, meanwhile the lowest values (14.96 and $13.83 \%)$ were recorded with 5-day interval in the $1^{\text {st }}$ and $2^{\text {nd }}$, respectively. In concern to purity percentage, analysis of variance showed significant response at $\mathrm{P}<0.01$ to irrigation intervals in the first season only. Where, inreasing irrigation intervals from 5 to 11 days increased purity from 78.96 to $82.85 \%$.

\subsubsection{Effect of plant densities:}

Plant density had significant effect at $\mathrm{P}<0.05$ on TSS in the $2^{\text {nd }}$ season and sucrose percentage in the $1^{\text {st }}$ season (Table 6). Moderate plant density $(28,000$ plants/fed.) gave the highest TSS $(20.11 \%)$. However, decreasing plant density from 46,000 to 20,000 plant fed $^{-1}$ decreased sucrose percentage from 18.86 to $18.30 \%$ in the first season. These reductions were by 0.58 and $2.06 \%$ for the highest plant density as compared with the lower densities (28,000 and 20,000 plant/fed., respectively). The 
Table (5): Some juice quality parameters of sugar beet as affected by irrigation intervals in 2006/2007 and 2007/2008 seasons

\begin{tabular}{c|cccccc}
\hline Parameters & \multicolumn{2}{|c}{ TSS \% } & \multicolumn{2}{c}{ Sucrose } & \multicolumn{2}{c}{ Juice purity \% } \\
\hline $\begin{array}{c}\text { Intervals } \\
\text { Irrigation (day) }\end{array}$ & $2006 / 07$ & $2007 / 08$ & $2006 / 07$ & $2007 / 08$ & $2006 / 07$ & $2007 / 08$ \\
\hline 5 & 18.78 & $18.82 \mathrm{c}$ & $14.96 \mathrm{c}$ & $13.83 \mathrm{c}$ & $78.96 \mathrm{c}$ & 73.38 \\
8 & 19.50 & $20.23 \mathrm{~b}$ & $15.82 \mathrm{~b}$ & $14.85 \mathrm{~b}$ & $81.10 \mathrm{~b}$ & 73.41 \\
11 & 19.63 & $21.33 \mathrm{a}$ & $16.28 \mathrm{a}$ & $15.33 \mathrm{a}$ & $82.85 \mathrm{a}$ & 71.63 \\
\hline F-test & $\mathrm{ns}$ & $*$ & $* *$ & $* *$ & $* *$ & $\mathrm{~ns}$ \\
\hline$* * *$ and & & & & & & \\
\hline
\end{tabular}

$*$ ** and $\mathrm{ns}=$ significant at $\mathrm{P}<0.05,0.01$ levels and not significant, respectively. Means have the same letters

Table (6):Some juice quality parameters of sugar beet as affected by plant densities in 2006/2007 and 2007/2008 seasons.

\begin{tabular}{c|cccccc}
\hline Trait & \multicolumn{2}{|c}{ TSS \% } & \multicolumn{2}{c}{$\begin{array}{c}\text { Sucrose } \\
\text { percentage } \%\end{array}$} & \multicolumn{2}{c}{ Juice purity \% } \\
\hline $\begin{array}{c}\text { Plant densities } \\
\text { (1000 plants/fed.) }\end{array}$ & $2006 / 07$ & $2007 / 08$ & $2006 / 07$ & $2007 / 08$ & $2006 / 07$ & $2007 / 08$ \\
\hline 46 & 20.05 & $19.82 \mathrm{~b}$ & $18.86 \mathrm{a}$ & 19.07 & 93.96 & 96.15 \\
28 & 20.46 & $20.11 \mathrm{a}$ & $18.75 \mathrm{~b}$ & 18.88 & 91.77 & 93.84 \\
20 & 20.15 & $19.02 \mathrm{~b}$ & $18.30 \mathrm{c}$ & 19.01 & 90.76 & 94.34 \\
\hline F-test & $\mathrm{ns}$ & $*$ & $*$ & $\mathrm{n}$ & $\mathrm{ns}$ & $\mathrm{ns}$ \\
\hline *,** and ns = significant at P< 0.05, 0.01 levels and not significant, respectively. Means have the same \\
letters are not significantly different at 5 \% level.
\end{tabular}

Table (7): Some juice quality parameters of sugar beet as affected by nitrogen fertilizer rates in 2006/2007 and 2007/2008 seasons:

\begin{tabular}{c|c|c|c|c|c|c}
\hline \hline Parameters & \multicolumn{2}{|c|}{ TSS \% } & \multicolumn{2}{c|}{ Sucrose percentage $\%$} & \multicolumn{2}{c}{ Juice purity $\%$} \\
\hline $\begin{array}{l}\text { Nitrogen } \\
\text { fertilizer rates } \\
\left(\mathrm{N} \mathrm{kg} \mathrm{fed}^{-1}\right)\end{array}$ & $2006 / 07$ & $2007 / 08$ & $2006 / 07$ & $2007 / 08$ & $2006 / 07$ & $2007 / 08$ \\
\hline 60 & $19.41 \mathrm{~d}$ & $20.33 \mathrm{~d}$ & $18.09 \mathrm{a}$ & $18.22 \mathrm{a}$ & $93.16 \mathrm{a}$ & $85.36 \mathrm{a}$ \\
80 & $20.22 \mathrm{c}$ & $21.41 \mathrm{c}$ & $17.25 \mathrm{c}$ & $17.80 \mathrm{bc}$ & $85.23 \mathrm{~b}$ & $83.03 \mathrm{~b}$ \\
100 & $22.01 \mathrm{~b}$ & $23.32 \mathrm{~b}$ & $17.84 \mathrm{bc}$ & $17.29 \mathrm{c}$ & $80.93 \mathrm{c}$ & $74.05 \mathrm{c}$ \\
120 & $25.35 \mathrm{a}$ & $25.50 \mathrm{a}$ & $16.30 \mathrm{~d}$ & $16.75 \mathrm{~d}$ & $64.30 \mathrm{~d}$ & $65.66 \mathrm{~d}$ \\
\hline F-test & $*$ & $*$ & $* *$ & $* *$ & $* *$ \\
\hline \hline
\end{tabular}

$*, * *$ and ns = significant at $\mathrm{P}<0.05,0.01$ levels and not significant, respectively. Means have the same letters are not significantly different at $5 \%$ level.

Table (8): Averages of root and sugar yields of sugar beet as affected by

irrigation intervals in 2006/2007 and 2007/2008 seasons

\begin{tabular}{c|cc|c|c}
\hline \hline Yield & \multicolumn{2}{|c|}{ Root yield } & $($ ton fed & \\
\hline & & \multicolumn{2}{c}{ Sugar yield } & $\left(\right.$ ton $\left.\mathrm{fed}^{-1}\right)$ \\
\hline $\begin{array}{c}\text { Irrigation } \\
\text { intervals (day) }\end{array}$ & $2006 / 2007$ & $2007 / 2008$ & $2006 / 2007$ & $2007 / 0208$ \\
\hline 5 & $32.21 \mathrm{a}$ & $33.62 \mathrm{a}$ & $4.81 \mathrm{a}$ & $4.65 \mathrm{~b}$ \\
8 & $29.85 \mathrm{~b}$ & $32.45 \mathrm{a}$ & $4.73 \mathrm{~b}$ & $4.82 \mathrm{a}$ \\
11 & $24.36 \mathrm{c}$ & $26.01 \mathrm{c}$ & $3.96 \mathrm{c}$ & $3.92 \mathrm{c}$ \\
F-test & $* *$ & $*$ & $* *$ & $* *$ \\
\hline \hline
\end{tabular}

letters are not significantly different at $5 \%$ level.

Table (9): Averages of root and sugar yields of sugar beet as affected by plant densities in 2006/2007 and 2007/2008 seasons

\begin{tabular}{|c|c|c|c|c|}
\hline Yield & \multicolumn{2}{|c|}{ Root yield (ton fed ${ }^{-1}$ ) } & \multicolumn{2}{|c|}{ "Sugar yield $\left(\right.$ ton fed $\left.^{-1}\right)$} \\
\hline $\begin{array}{l}\text { Plant densities } \\
\text { (1000 plants/fed.) }\end{array}$ & $2006 / 2007$ & $2007 / 2008$ & $2006 / 2007$ & $2007 / 2008$ \\
\hline 46 & $35.98 \mathrm{a}$ & $35.14 \mathrm{ab}$ & $6.73 \mathrm{a}$ & $6.71 \mathrm{a}$ \\
\hline 28 & $30.88 \mathrm{~b}$ & $35.47 \mathrm{a}$ & $5.76 \mathrm{~b}$ & $6.64 \mathrm{~b}$ \\
\hline 20 & $15.16 \mathrm{c}$ & $15.18 \mathrm{c}$ & $2.78 \mathrm{c}$ & $2.82 \mathrm{c}$ \\
\hline F-test & $* *$ & $* *$ & $* *$ & $* *$ \\
\hline
\end{tabular}

$*, * *$ and $\mathrm{ns}=$ significant at $\mathrm{P}<0.05,0.01$ levels and not significant, respectively. Means with the same letters are not significantly different at $5 \%$ level. 
reduction in sucrose percentage may refer to that widenenig plant spacing may increase root weight and there is a negative correlation between root weight and its sucrose content.

\subsubsection{Effect of nitrogen fertilizer rates:}

A significant response at $\mathrm{P} \leq 0.05$ of total solube solids (TSS) percentage to nitrogen fertilizer rates was observed in both seasons (Table 7). Where, increasing nitrogen fertilizer rates from 60 up to $120 \mathrm{~kg} \mathrm{~N}$ fed $^{-1}$ increased TSS percentage from 19.41 and $20.33 \%$ up to 25.35 and $25.50 \%$ in the $1^{s t}$ and $2^{\text {nd }}$ seasons, respectively. However, increasing nitrogen fertilizer rates depressed root sucrose percentage in both seasons Table (7). The highest sucrose percentages (18.09 and $18.22 \%$ ) were achieved when sugar beet was fertilized at the rate of 60 $\mathrm{kg} \mathrm{N} \mathrm{fed}^{-1}$ in 2006/2007 and 2007/2008 seasons, respectively. This decrease in root sucrose content in response to increasing nitrogen fertilizer rates may be due to excessive amounts of nitrogen which stimulate beet plants to transfer more photosynthates to the top and resulted in a decrease in root content of sucrose. In other words, this reduction in root sucrose percentage as a result of applying nitrogen fertilization is due to nitrogen role in increasing root dimensions and tissue water content as well as non-sucrose substances such as proteins and alpha amino acids, hence decreasing root sucrose content.

In contrast, applying $60 \mathrm{~kg} \mathrm{~N}^{-1} \mathrm{~d}^{-1}$ gave the highest purity percentages (93.16 and $91.85 \%$ ) in the two respective seasons, followed by $80 \mathrm{~kg}$ $\mathrm{N}$ fed $^{-1}$ treatment. It could be concluded that increasing nitrogen fertilizer rates tended to reduce purity percentage. The drop in juice purity of sugar beet in response to nitrogen fertilization may be due to the increases of amino compound concentrations caused by excessive uptake of nitrate late in the season.

In this concern, Follet (1991) found that the increases in cation concentrations are associated with the decreases in the sucrose percentage, associated with an increase in water content (low dry content) in fresh sugar beet roots and caused dillution in sucrose cocentration. However, the non-sucrose constituents that decrease sucrose crystallization may include carbonate, chloride, amino acids, betaine, glutamic acid and sulphate. Therefore, not only sucrose percentage but also juice purity are expected to increase as the sum of cations decrease.

\subsection{Root and sugar yields 3.3.1. Effect of irrigation intervals}

Data presented in Table (8) show that root and sugar yields were significantly affected by irrigation intervals in both seasons. Increasing soil moisture stress (irrigation every 11 days) reduced sharply root yield $\left(24.46\right.$ ton $\left.\mathrm{fed}^{-1}\right)$ as compared with non- stressed plants (irrigation every 5 days; 32.21 ton $\mathrm{fed}^{-1}$ ) in the first season. This was true in the second season, where, 5-day treatment increased root yield by 3.6 and $29.3 \%$ as compared by 8 and 11-day treatment were produced by irrigating sugar beet plants every 5 days in both respective seasons. However, 5 and 11 - day treatments resulted in a significant reduction in root yield and they were by 4.5 , respectively. Also, the highest sugar yields (4.81 and 4.82 ton $\mathrm{fed}^{-1}$ ) were reported with irrigation every 5 days in the $1^{s t}$ and 8 days in $2^{\text {nd }}$ season, respectively. Irrigation at close intervals might help in solublization and absorption of mineral nutrients from the soil to plant system which led to increase in total dry weight per plant and resulted in heavier root and sugar yield. These results are in accordance with those reported by Dunham (1993); Sorour, (1995); Besheit, et al. (1996) and EL-Maghraby et al. (2008).

\subsubsection{Effect of plant densities:}

Analysis of variance showed that plant densities had highly significant effects on sugar beet yield in both seasons (Table 9). Decreasing

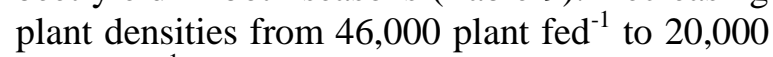
plant fed $^{-1}$ decreased root yield from 35.98 to 15.16 ton $\mathrm{fed}^{-1}$ in the first season. Moderate plant density $(28,000$ plants fed- 1$)$ gave the maximum root yield $\left(35.47\right.$ ton $\left.\mathrm{fed}^{-1}\right)$ in the $2^{\text {nd }}$ season. However, decreasing plant density from 46 to 20 thousands plants/fed -1 decreased sugar yield from 6.73 and 6.71 to 2.78 and 2.82 ton $\mathrm{fed}^{-1}$ in the two respective seasons. These results may refer to the increasing of plants number per unit area which resulted in more yield of roots and sugar. These results are in the same line of those obtained by Yousif (2001) and ELMaghraby et al. (2008).

\subsubsection{Effect of nitrogen fertilizer rates:}

Increasing nitrogen fertilizer rates increased significantly and gradually root yield in both seasons and sugar yield in the second season (Table 10). Application of $120 \mathrm{~kg} \mathrm{~N}$ fed $^{-1}$ produced the heaviest root yield (33.15 and 35.22 ton $\mathrm{fed}^{-1}$ ) in both respective seasons. The opposite trend was found for sugar yield in the second season, where, the highest nitrogen rate $\left(120 \mathrm{~kg} \mathrm{~N} \mathrm{fed}^{-1}\right)$ increased sugar yield by 21.2 , 14.1 and $0.37 \%$ as compared with the lowest rates $\left(60,80\right.$ and $100 \mathrm{~kg} \mathrm{~N}^{-1}$, respectively). 
The difference between 100 and $120 \mathrm{~kg} \mathrm{~N} \mathrm{fed}^{-1}$ was not significant, so adding nitrogen fertilizer more than $100 \mathrm{~kg} \mathrm{~N}^{-1}$ will not be econmoic for maximizing sugar beet productivity. The increases in root yield as a result of increasing nitrogen fertilizer rates may be due to the importance of nitrogen as one of the macronutrient elements for plant nutrition and its role in increasing vegetative growth through enhancing leaf initiation, increment chlorophyll concetration in leaves which resulted in improving photosynthesis process. Moreover, the role of nitrogen in accumulating carbohydrates, translocated from leaves to roots which in turn enhanced root fresh weight (Table 2 ) and finally root and sugar yields per unit area. These results are in full agreement with those obtained by El-Kassed et al. (1993); ElGeddawy et al. (2006) and Seadh (2008).

\subsection{Water relationships}

Sugar beet water relationships responded significantly to all the studied factors and insignificantly to any of the possible interactions (Table 11). This may be due to the individual effect of each factor.

\subsubsection{Effect of irrigation intervals}

Irrigation intervals affected significantly all the studied water relations except water use efficiency of sugar yield in the second season. Increasing irrigation intervals from 5 to 11 days decreased significantly and sharply water consumptive use (CU) from 3279 and 3511 to 2123 and $2311 \mathrm{~m}^{3} \mathrm{fed}^{-1}$ in $1^{\text {st }}$ and $2^{\text {nd }}$ seasons, respectively (Table 11). However, the maximum values of water use efficiency (WUE) calculated either as root in both seasons or sugar in the first season per cubic meter of water were recorded when sugar beet plants irrigated every 8 days in both growing seasons. This result is mainly due to higher root snd sugar yields produced with this irrigation interval treatment (Table, 8). Meanwhile, it could be noticed that the lowest values of WUE ( $\mathrm{kg}$ roots and/or $\mathrm{kg}$ sugar $/ \mathrm{m}^{3}$ water) were obtained by irrigation every 5 -days interval in both seasons. These results could be attributed to higher water consumptive use amounted 3279 and $3511 \mathrm{~m}^{3} \mathrm{fed}^{-1}$ in the $1^{\text {st }}$ and $2^{\text {nd }}$ seasons, respectively. These results are in full agreement with those reported by Mohamed, et al. (2000) and Fabeiro et al. (2003).

\subsubsection{Effect of plant density}

The obtained results showed that $\mathrm{CU}$ values were slightly higher (2454 and $2480 \mathrm{~m}^{3} \mathrm{fed}^{-1}$ ) when beet was cultivated at plant density of 20,000 plants fed $^{-1}$ than those recorded by the other higher plant densities. Where, these increases were by 1.4 and $0.95 \%$ in $1^{\text {st }}$ season and by 1.97 and $0.57 \%$ in $2^{\text {nd }}$ season as compared with 46,000 and 28,000 plants fed ${ }^{-1}$, respectively (Table12). This result may refer to less competition between plants at lowest plant density for absorbing water and nutrients as compared with the other studied plant denities. Concerning to WUE, the highest plant density $\left(46,000\right.$ plants fed $\left.^{-1}\right)$ generally attained higher values of WUE ( $\mathrm{kg}$ roots and sugar/ $\mathrm{m}^{3}$ ) compared with the other lowest densities in both seasons. This result is due to higher root and sugar yields (Table 9) and lower water consumptive use with the highest plant density compared with the other lowest plant densities. Similar trend was obtained by Taleghani et al. (2004) under different environments.

\subsubsection{Effect of nitrogen fertilizer rates}

Nitrogen fertilizer rates affected significantly the consumptive use (CU) and water use efficiency (WUE) calculated either as $\mathrm{kg}$ root $/ \mathrm{m}^{3}$ in both seasons or $\mathrm{kg}$ sugar $/ \mathrm{m}^{3}$ in the second season only (Table 13). Applying $100 \mathrm{~kg}$ $\mathrm{N}$ fed ${ }^{-1}$ gave the maximum values of CU (3280 and $\left.3312 \mathrm{~m}^{3} \mathrm{fed}^{-1}\right)$. These superiorities were by 4.88 and $3.18 \%$ in 2006/2007 season and by 16.21 and $3.47 \%$ in 2007/2008 season as compared with the two lower respective rates. However, the differences between applying 100 or $120 \mathrm{~kg} \mathrm{~N}$ fed $^{-1}$ had insignificant reduction (by 2.13 and $0.94 \%$ ) in both seasons, respectively; so, more nitrogen fertilizer rates will not be economical. Also, the ability of sugar beet to use irrigation water more efficiently was achieved when the plants were fertilized at the rate of 120 $\mathrm{kg} \mathrm{N} \mathrm{fed}^{-1}$ (Table 13). This may be due to the highest root yield which was obtained with the highest nitrogen rate (Table10). However, statistical analysis showed that there was no significant effect of nitrogen fertilizer rates on WUE ( $\mathrm{kg}$ sugar $/ \mathrm{m}^{3}$ water) in the first season. This mainly refers to the non-significant differences of sugar yield in response to different nitrogen fertilizer rates in the $1^{s t}$ season (Table 10). However, the maximum value of WUE (1.92 $\mathrm{kg}$ sugar $/ \mathrm{m}^{3}$ water) was obtained with the highest nitrogen fertilizer rate $\left(120 \mathrm{~kg} \mathrm{~N} \mathrm{fed}^{-1}\right)$. Similar results were recorded by Koszanski and Roy (1995) and El-Zayat (2000).

\subsection{Effect of interactions}

Statistical analysis showed that there were no significant effects of all first and second order interactions for the studied parmeters in both seasons except the interaction of irrigation 
Table (10): Averages of root and sugar yields of sugar beet as affected by Nitrogen fertilizer rates in 2006/2007 and 2007/2008 seasons

\begin{tabular}{c|cc|c|c}
\hline \hline Yield & \multicolumn{2}{|c}{ Root yield } & $($ ton fed & -1 \\
\hline \\
$\begin{array}{c}\text { Nitrogen rate } \\
\left(\mathrm{N} \mathrm{kg} \mathrm{fed}^{-1}\right)\end{array}$ & $2006 / 2007$ & $2007 / 2008$ & $2006 / 2007$ & $2007 / 2008$ \\
\hline 60 & $24.82 \mathrm{~d}$ & $26.62 \mathrm{~d}$ & $4.48 \mathrm{~d}$ & 4.86 \\
80 & $27.65 \mathrm{c}$ & $29.13 \mathrm{c}$ & $4.76 \mathrm{c}$ & 5.19 \\
100 & $30.33 \mathrm{~b}$ & $32.66 \mathrm{~b}$ & $5.41 \mathrm{ab}$ & 5.65 \\
120 & $33.15 \mathrm{a}$ & $35.22 \mathrm{a}$ & $5.43 \mathrm{a}$ & 5.91 \\
F-test & $* *$ & $* *$ & $*$ & $\mathrm{~ns}$ \\
\hline \hline
\end{tabular}

Table (11): Some water relationships of sugar beet as affected by irrigation intervals in 2006/2007 and 2007/2008 seasons

\begin{tabular}{|c|c|c|c|c|c|c|}
\hline \multirow{2}{*}{$\begin{array}{l}\text { Water } \\
\text { relatioships }\end{array}$} & \multicolumn{2}{|c|}{$\begin{array}{c}\mathrm{CU} \\
\left(\mathrm{m}^{3} \mathrm{fed}^{-1}\right)\end{array}$} & \multicolumn{2}{|c|}{$\begin{array}{c}\text { WUE } \\
\text { (kg root } \mathrm{m}^{-3} \text { water) }\end{array}$} & \multicolumn{2}{|c|}{$\begin{array}{c}\text { WUE } \\
\left(\mathrm{kg} \mathrm{sugar} \mathrm{m}^{-3} \text { water }\right)\end{array}$} \\
\hline & $2006 / 2007$ & $2007 / 2008$ & $2006 / 2007$ & $2007 / 2008$ & $2006 / 2007$ & $2007 / 2008$ \\
\hline 5 & $3279 \mathrm{a}$ & $3511 \mathrm{a}$ & $9.84 \mathrm{c}$ & $9.58 \mathrm{c}$ & $1.45 \mathrm{c}$ & 1.34 \\
\hline 8 & $2343 \mathrm{~b}$ & $2555 \mathrm{~b}$ & $12.75 \mathrm{a}$ & $12.76 \mathrm{a}$ & $2.03 \mathrm{a}$ & 1.89 \\
\hline 11 & $2123 \mathrm{c}$ & $2311 \mathrm{c}$ & $11.46 \mathrm{~b}$ & $11.28 \mathrm{~b}$ & $1.88 \mathrm{~b}$ & 1.71 \\
\hline F-test & $* *$ & $* *$ & ** & $* *$ & $* *$ & $\mathrm{~ns}$ \\
\hline
\end{tabular}

$*, * *$ and $\mathrm{ns}=$ significant at $\mathrm{P}<0.05,0.01$ levels and not significant, respectively. Means with the same letters are not significantly different at $5 \%$ level.

Table (12): Some water relationships of sugar beet as affected by plant densities in 2006/2007 and 2007/2008 seasons

\begin{tabular}{|c|c|c|c|c|c|c|}
\hline \multirow{2}{*}{$\begin{array}{c}\text { Water } \\
\text { relationships } \\
\text { Plant densities } \\
\text { (1000 plant/ fed) }\end{array}$} & \multicolumn{2}{|c|}{$\begin{array}{c}\mathrm{CU} \\
\left(\mathrm{m}^{3} \mathrm{fed}^{-1}\right)\end{array}$} & \multicolumn{2}{|c|}{$\begin{array}{c}\text { WUE } \\
\left(\mathrm{kg} \text { root } \mathrm{m}^{-3} \text { water }\right)\end{array}$} & \multicolumn{2}{|c|}{$\begin{array}{c}\text { WUE } \\
\text { (kg sugar } \mathrm{m}^{-3} \text { water) }\end{array}$} \\
\hline & $2006 / 2007$ & $2007 / 2008$ & $2006 / 2007$ & $2007 / 2008$ & $2006 / 2007$ & $2007 / 2008$ \\
\hline 46 & $2420 \mathrm{c}$ & $2432 \mathrm{c}$ & $14.85 \mathrm{a}$ & $14.44 \mathrm{a}$ & $2.75 \mathrm{a}$ & $2.76 \mathrm{a}$ \\
\hline 28 & $2431 \mathrm{~b}$ & $2466 \mathrm{~b}$ & $12.69 \mathrm{~b}$ & $14.38 \mathrm{ab}$ & $2.34 \mathrm{~b}$ & $2.70 \mathrm{a}$ \\
\hline 20 & $2454 \mathrm{a}$ & $2480 \mathrm{a}$ & $6.17 \mathrm{c}$ & $6.11 \mathrm{c}$ & $1.15 \mathrm{c}$ & $1.11 \mathrm{c}$ \\
\hline F-test & $* *$ & $* *$ & $* *$ & $* *$ & $* *$ & $* *$ \\
\hline
\end{tabular}

Table (13): Some water relationships of sugar beet as affected by nitrogen fertilizer rates in $2006 / 2007$ and $2007 / 2008$ seasons

\begin{tabular}{ccccccc}
\hline $\begin{array}{c}\text { Water } \\
\text { relationships }\end{array}$ & $\begin{array}{c}\mathrm{CU} \\
\left(\mathrm{m}^{3} \mathrm{fed}^{-1}\right)\end{array}$ & $\begin{array}{c}\text { WUE } \\
\left(\mathrm{kg} \mathrm{root} \mathrm{m}^{-3} \text { water }\right)\end{array}$ & $\begin{array}{c}\text { WUE } \\
\left(\mathrm{kg} \mathrm{sugar} \mathrm{m}^{-3} \text { water }\right)\end{array}$ \\
\hline $\begin{array}{c}\text { Nitrogen } \\
\begin{array}{c}\text { fertilizer rates } \\
\left(\mathrm{N} \mathrm{kg} \mathrm{fed}^{-1}\right)\end{array}\end{array}$ & $2006 / 2007$ & $2007 / 2008$ & $2006 / 2007$ & $2007 / 2008$ & $2006 / 2007$ & $2007 / 2008$ \\
\hline 60 & $3120 \mathrm{~d}$ & $2850 \mathrm{~d}$ & $7.88 \mathrm{~d}$ & $9.34 \mathrm{~d}$ & 1.45 & $1.72 \mathrm{~b}$ \\
80 & $3179 \mathrm{c}$ & $3201 \mathrm{c}$ & $8.66 \mathrm{c}$ & $9.11 \mathrm{c}$ & 1.46 & $1.63 \mathrm{~d}$ \\
100 & $3280 \mathrm{a}$ & $3312 \mathrm{a}$ & $9.26 \mathrm{~b}$ & $9.86 \mathrm{~b}$ & 1.64 & $1.70 \mathrm{c}$ \\
120 & $3210 \mathrm{~b}$ & $3281 \mathrm{~b}$ & $10.33 \mathrm{a}$ & $10.73 \mathrm{a}$ & 1.68 & $1.80 \mathrm{a}$ \\
\hline F-test & $* *$ & $* *$ & $* *$ & $*$ & $\mathrm{~ns}$ & $* *$ \\
\hline
\end{tabular}

*, ** and $\mathrm{ns}=$ significant at $\mathrm{P}<0.05,0.01$ levels and not significant, respectively. Means with the same letters are not significantly different at $5 \%$ level. 
Table (14): Interaction effect between irrigation intervals and nitrogen fertilizer rates on root and sugar yields in 2006/2007 season.

\begin{tabular}{|c|c|c|c|c|c|c|c|c|}
\hline \multirow[t]{2}{*}{ Parampeters } & \multicolumn{4}{|c|}{ Root yield (ton fed ${ }^{-1}$ ) } & \multicolumn{4}{|c|}{ Sugar yield (ton fed ${ }^{-1}$ ) } \\
\hline & \multicolumn{8}{|c|}{ Nitrogen fertilizer rates $\left(\mathrm{N} \mathrm{kg} \mathrm{fed}^{-1}\right)$} \\
\hline $\begin{array}{l}\text { Irrigation } \\
\text { intervals } \\
\text { (day) }\end{array}$ & 60 & 80 & 100 & 120 & 60 & 80 & 100 & 120 \\
\hline 5 & $27.74 \mathrm{ef}$ & $32.48 \mathrm{bc}$ & $33.65 \mathrm{~b}$ & $37.72 \mathrm{a}$ & $3.76 \mathrm{~h}$ & $4.24 \mathrm{~g}$ & $5.83 \mathrm{a}$ & $5.18 \mathrm{c}$ \\
\hline 8 & 27.84 ef & $28.72 \mathrm{de}$ & $29.64 \mathrm{c}$ & $\begin{array}{c}32.63 \\
\text { bc }\end{array}$ & $4.86 \mathrm{def}$ & $\begin{array}{c}4.68 \\
\text { ef }\end{array}$ & $4.88 \mathrm{def}$ & $5.40 \mathrm{bc}$ \\
\hline 11 & $19.31 \mathrm{i}$ & $22.05 \mathrm{~h}$ & $26.81 \mathrm{f}$ & $25.24 \mathrm{~g}$ & $3.42 \mathrm{i}$ & $\begin{array}{c}3.62 \\
\mathrm{hi}\end{array}$ & $4.62 \mathrm{f}$ & $4.78 \mathrm{ef}$ \\
\hline F-Test & \multicolumn{4}{|c|}{ ** } & \multicolumn{4}{|c|}{$* *$} \\
\hline
\end{tabular}

Table (15): Interaction effect of irrigation intervals, plant densities and nitrogen fertilizer rates on root and sugar yields in 2007/2008 season.

\begin{tabular}{|c|c|c|c|c|c|c|c|c|c|}
\hline \multicolumn{2}{|c|}{ Parampeters } & \multicolumn{4}{|c|}{ Root yield (ton fed ${ }^{-1}$ ) } & \multicolumn{4}{|c|}{ Sugar yield (ton fed $^{-1}$ ) } \\
\hline \multirow{2}{*}{$\begin{array}{l}\text { Irrigation } \\
\text { intervals } \\
\text { (day) }\end{array}$} & \multirow{2}{*}{$\begin{array}{c}\text { Plant } \\
\text { densities } \\
(1000 \\
\text { plants/fed })\end{array}$} & \multicolumn{8}{|c|}{ Nitrogen fertilizer rates $\left(\mathrm{N} \mathrm{kg} \mathrm{fed}^{-1}\right)$} \\
\hline & & 60 & 80 & 100 & 120 & 60 & 80 & 100 & 120 \\
\hline \multirow{3}{*}{5} & 46 & $38.75 \mathrm{ij}$ & $41.45 \mathrm{~h}$ & $46.47 \mathrm{c}$ & $44.77 \mathrm{e}$ & $3.32 \mathrm{j}$ & $3.61 \mathrm{~h}$ & $3.80 \mathrm{e}$ & $3.94 \mathrm{~d}$ \\
\hline & 28 & $38.88 \mathrm{i}$ & $41.70 \mathrm{gh}$ & $43.73 \mathrm{f}$ & $45.28 \mathrm{~d}$ & $3.30 \mathrm{j}$ & $3.51 \mathrm{i}$ & $3.77 \mathrm{f}$ & $3.91 \mathrm{~d}$ \\
\hline & 20 & $18.65 \mathrm{uv}$ & $21.11 \mathrm{~s}$ & $22.83 \mathrm{rs}$ & $25.68 \mathrm{p}$ & $1.30 \mathrm{rs}$ & $1.52 \mathrm{r}$ & $1.71 \mathrm{q}$ & $2.01 \mathrm{n}$ \\
\hline \multirow{3}{*}{8} & 46 & $37.91 \mathrm{k}$ & $43.42 \mathrm{f}$ & $44.98 \mathrm{de}$ & $49.32 \mathrm{ab}$ & $3.24 \mathrm{k}$ & $3.82 \mathrm{e}$ & $4.01 \mathrm{c}$ & $4.39 \mathrm{a}$ \\
\hline & 28 & $38.18 \mathrm{jk}$ & 44.02 ef & $45.91 \mathrm{~d}$ & $49.65 \mathrm{a}$ & $3.21 \mathrm{k}$ & $3.76 \mathrm{f}$ & $3.92 \mathrm{~d}$ & $4.33 \mathrm{~b}$ \\
\hline & 20 & $18.42 \mathrm{uv}$ & $23.24 \mathrm{qr}$ & $25.21 \mathrm{p}$ & $27.80 \mathrm{op}$ & $1.23 \mathrm{t}$ & $1.74 \mathrm{q}$ & $1.94 \mathrm{p}$ & $2.20 \mathrm{o}$ \\
\hline \multirow{3}{*}{11} & 46 & $30.98 n$ & $34.93 \mathrm{~lm}$ & $40.96 \mathrm{hi}$ & $44.88 \mathrm{de}$ & $2.59 \mathrm{~m}$ & $2.69 \mathrm{kl}$ & $3.32 \mathrm{ij}$ & $3.69 \mathrm{~g}$ \\
\hline & 28 & $34.49 \mathrm{~lm}$ & 35.461 & $41.84 \mathrm{gh}$ & $45.58 \mathrm{~d}$ & $2.54 \mathrm{n}$ & $2.63 \mathrm{kl}$ & $3.24 \mathrm{j}$ & $3.63 \mathrm{~h}$ \\
\hline & 20 & $18.07 \mathrm{v}$ & 18.93 tuv & $21.43 \mathrm{~s}$ & $23.67 \mathrm{qr}$ & $0.91 \mathrm{u}$ & $1.03 \mathrm{st}$ & $1.28 \mathrm{~s}$ & $1.51 \mathrm{r}$ \\
\hline \multicolumn{2}{|c|}{ F-Test } & \multicolumn{4}{|c|}{$* *$} & \multicolumn{4}{|c|}{$* *$} \\
\hline
\end{tabular}

$*$ and $* *=$ significant at $\mathrm{P}<0.05$ and 0.01 levels. Means with the same letters are not significantly different at $\mathrm{P}<0.05 \%$ level

intervals and nitrogen fertilizer rates on root and sugar yields in the $1^{s t}$ season and the second order interaction on root and sugar yields in the $2^{\text {nd }}$

seasons. This may be due to the individual effect of each factor.

There was highly significant effect of irrigation intervals and nitrogen fertilizer rate interaction on root and sugar yields in the first season (Table 14). Where, The maximum root yield ( 37.72 ton $\mathrm{fed}^{-1}$ ) was obtained when beets were irrigated every 5 days and fertilized at the rate of $120 \mathrm{~kg} \mathrm{~N} \mathrm{fed}^{-1}$, while, the minimum one (19.31 ton $\mathrm{fed}^{-1}$ ) was achieved from the interaction of11-days interval with $60 \mathrm{~kg} \mathrm{~N}^{-1} \mathrm{~d}^{-1}$. However, irrigating beets every 5 days under nitrogen fertilizer rate of $100 \mathrm{~kg} \mathrm{~N} \mathrm{fed}^{-1}$ gave the highest sugar yield $\left(5.83\right.$ ton $\left.\mathrm{fed}^{-1}\right)$, but the lowest one $\left(3.42\right.$ ton $\left.\mathrm{fed}^{-1}\right)$ was gained with 11day inteval and $60 \mathrm{~kg} \mathrm{~N} \mathrm{fed}^{-1}$ interaction.

Concerning to the second order interaction, irrigation every 8 days at moderate plant density $\left(28,000\right.$ plants/fed) with $120 \mathrm{~kg} \mathrm{~N} \mathrm{fed}^{-1}$ treatment gave the maximum root yield (49.65 ton $\mathrm{fed}^{-1}$ ), while, the minimum value $\left(18.07\right.$ ton $\left.\mathrm{fed}^{-1}\right)$ was achieved from the interaction of irrigation every 11 at 20,000 plant/fed. with nitrogen fertilizer rate of $60 \mathrm{~kg} \mathrm{~N}^{-1}$ (Table, 15). However, moderate water stress (8-days) and higest plant density $(46,000 \mathrm{plant} / \mathrm{fed})$ under the rate of 120 $\mathrm{kg} \mathrm{N} \mathrm{fed}{ }^{-1}$ gave the optimum sugar yield (4.39 ton $\left.\mathrm{fed}^{-1}\right)$, meanwhile, the lowest sugar yield $\left(0.91\right.$ ton $\left.\mathrm{fed}^{-1}\right)$ was gained from irrigation every 11 day with the lowest plant density and nitrogen fertilizer rate.

\section{CONCLUSION}

Generally, it is recommended that irrigating sugar beet plants every 8 days with plant density of 46,000 plant/fed and nitrogen fertilization at the rate of $100 \mathrm{~kg} \mathrm{~N} \mathrm{fed}^{-1}$ is the best combination for the optium sugar yield and the most efficient 
water use under sandy and newly reclaimed soils conditions of North Sinai Governorate.

\section{REFERENCES}

Azzazy N. B. (1998). Effect of sowing date, irrigation intervals and nitrogen fertilization on yield and quality of sugar beet under upper Egypt conditions. Egypt. J. Agric. Res., 76 (3): 1099-1133.

Basha H. A. (1999). Response of two sugar beet cultivars to level and method of nitrogen application in sandy soil. Zagazig J. Agric. Res. , 26 (1): 11-26.

Besheit S. Y., Mekki B. B. and Beshay G. M. (1996). Effect of different levels of water supply on sugar beet yield and quality in calcareous soils. J. Agric. Sci. Mansoura Univ., 21 (10): 3429-3436.

Carruthers A. and Oldfield J. E. T. (1960). Methods for assessment of beet quality. Int. Sugar J., 63: 72-74.

Duncan D. B. (1990). Multiple range and multiple $\mathrm{F}$ test, Biometrics, 11: 1-24.

Dunham R. J. (1993). Water use and irrigation. p. 279-309. In D. A. Cooke and R. K. Scott. The Sugar Beet Crop. Chapman \& Hall, 2-6 Boundary Row, London ,UK.

EL-Geddawy I. H., EL-Keredy M. S., Omar A. M. and EL-Moghazy, A. (2008). Growth and chemical constituents of sugar beet as affected by nitrogen sources and rates and boron fertilizer. Proc. Int. Conf. "Meeting the Challenge of Sugar Crops \& Integrated Industires in Developing Countries", 1114 Sept. AL-Arish, Egypt, : 75-82.

EL-Geddawy I. H., EL-Shafai A. M. A. and Azzazy N. B. (2006). Yield and quality of some sugar beet varities as affected by planting densities and nitrogen fertilization. J. Agric. Sci. Mansoura Univ., 31 (1): 43-54.

EL-Kassed F. A., EL-Garabawy A. A. and Besheit S. Y. (1993). Yield of sugar beet and quality as affected by nitrogen and phosphorus rates in calcareous soils. J. Agric. Sci. Mansoura Univ., 18 (2): 581587.

EL-Maghraby S. S., Gomaa M. A., EL-Banna M. N. and Hassan H. M. S. (2008). Response of sugar beeet to some mechanical management practices, irrigation and plant densities: yield and quality parameters. Proc. Int. Conf."Meeting the Challenge of Sugar Crops \& Integrated Industries in
Developing Countries", EL-Arish, Egypt, : 83-90.

EL-Maghraby S. S., Shehata M.M. and Tawfik, Y. H. (1998). Effect of soil and foliar application of nitrogen and potassium on sugar beet. Egypt. J. Agric. Res., 75 (2) : 665-679.

EL-Sayed E. A. B. (2006). Effect of Organic, Biofertilization and Plant Density on Yield and Quality of Sugar Beet. Ph.D. Thesis, Fac. Agric., Alex. Univ., Egypt.

EL-Shafai A. M. A. (2000). Effect of nitrogen and potassium fertilization on yield and quality of sugar beet in Sohag. J. Agric. Res., 78(2): 759-767.

EL-Zayat M. M. T. (2000). Effect of Irrigation Regimes and Fertilization on Sugar Beet. Ph.D. Thesis. Fac. Agric. Tanta Univ. Khafr EL-Sheikh.

Fabeiro C., Martin de Santa Olalla F., Lopez R. and Dominguez A. (2003). Production and quality of sugar beet (Beta vulgaris, L.) cultivated under controlled deficit irrigation conditions in a semi-arid climate. Agric. Water Management, 62: 215-227.

Follett R. F. (1991). Seasonal sucrose, dry matter and cation concentrations of sugar beet as influenced by variety and $\mathrm{N}$-fertilization. Commu. Soil Sci. Plant Anal., 22 (9-10): 893-906.

Ibrahim M. M., EL-Aref K. A. O. and Abo ELHamd A. S. (2005). Effect of nitrogen and phosphorus fertilization on yield and quality of two sugar beet varieties under Assuit Governorate conditions. Zagazig J. Agric. Res., 32 (4): 1087-1103.

Israelsen, O. W. and Hansen V. E. (1962). Irrigation Principles and Practicies. $4^{\text {th }}$ Ed., John Willey and Sons Inc., New York.

Khater M. A. A. (1999). Responses of Sugar Beet to Irrigation Intervals, Sulphur Aplication and Ntrogen Frtilization. Ph.D. Thesis, Fac. Agric. Saba Basha, Alex. Univ., Egypt.

Koszanski Z. S. K. and Roy M. (1995). Effect of sprinkler irrigation and nitrogen application on sugar and fodder beet cultivated in a good rye complex soil. III. Water management and chemical properties of the soil. Zeszyty Naukowe Akademii Rolniczej w Szczecinie, Rolnictwo, Poland., 59: 73-79 (c.a. Abst., 1996-1998). 
Mohamed K. A, EL-Shafai A. M. A. and ELGeddawy I. H. (2000). Effect of sowing patterns and irrigation on yield and quality of sugar beet. Egypt. J. Appl. Sci., 15 (2): 56-67.

Ouda S. M. M., EL-Shafai A. M. A. and Azzazy N. B. (1999). Effect of farmyard manure and nitrogen fertilization on yield and quality of sugar beet in sandy soil. Zagazig J. Agric. Res., 26 (6) : 1487-1493.

Seadh S. E. (2008). Some factors affecting sugar beet productivity under newly reclaimed sandy soils. Proc. Int. Conf."Meeting the Challenge of Sugar Crops \& Integrated Industires in Developing Countries", ELArish, Egypt. : 110-115.

Shams EL-Din H. A. (2000). Effect of water application levels and different wetting depth on sugar beet yield and its water relations at north Delta., J. Agric. Sci. Mansoura Univ., 27 (6): 5931-5939.

Snedecor G. W. and Cochran W. G. (1990). Statistical Methods. $8^{\text {th }}$ Ed. Iowa State Univ. Press Ames, Iowa, USA.
Sorour S. Gh. R. (1995). Response of sugar beet to irrigation regimes and plant population. Egypt. J. Appl. Sci., 10 (8) : 648-668.

Taleghani D.F., Tohidloun G., Gohari J. „Habib D., Sadeghian Y. and Mesbah M. (2004). Improvement for water productivity in surface irrigation system by changing the plant spacing in sugar beet cultivation. Proc. $4^{\text {th }}$ International Crop Science Congress Brisbane, Australia, 26 Sep.-2 Oct. (www.cropscience.org.au).

Vites V. G. (1965). Increasing water use efficiency by soil management in plant environment and efficient water use efficiency. J. Amer. Soc. Agron., 26 : 537 546.

Winter R. S. (1980). Suitability of sugar beet for limited irrigation in a semi-arid climate., Agron. J., 72 (1): 118-123.

Yousif H. Y. M. (2001). Agronomic Studies on Sugar Beet. M.Sc. Thesis, Fac. Agric., Zagazig Univ., Egypt.

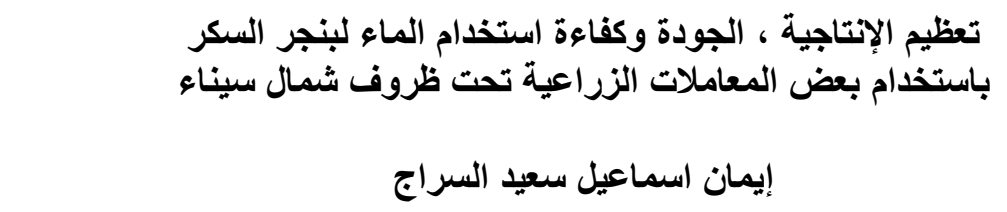

قسم الإنتاج النباتى- كلية العلوم الزر اعية البيئية بالعريش - جامعة قناة السويس- مصر

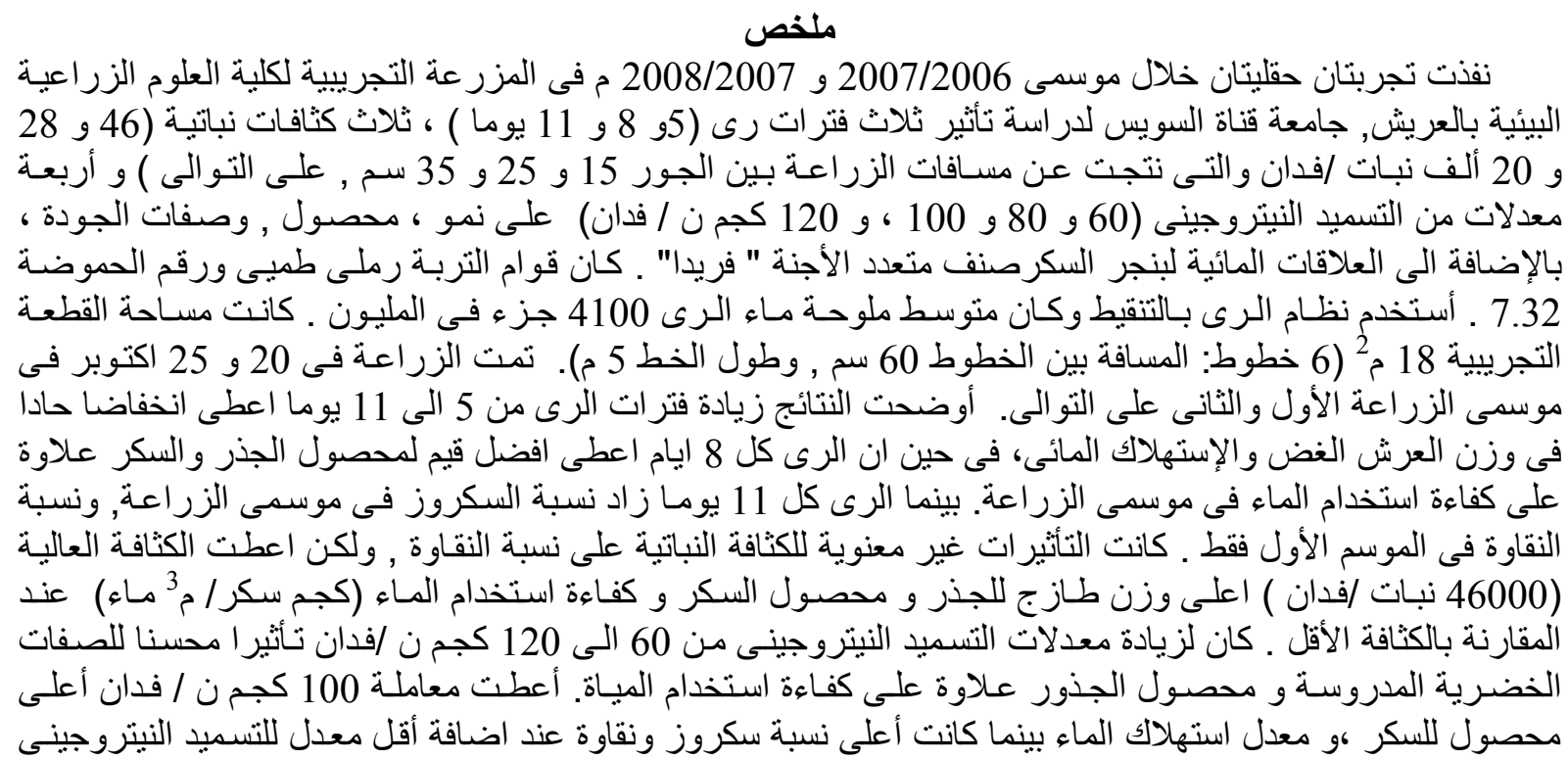

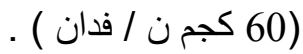




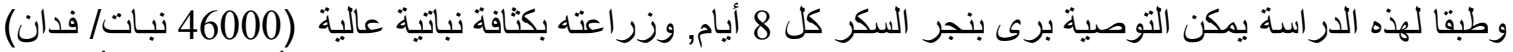

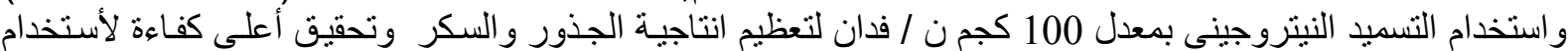

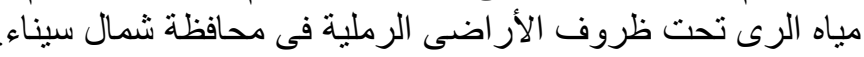

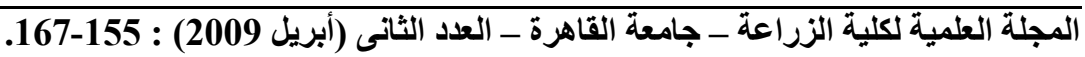


